\title{
Improvement of productivity and polysaccharide-protein complex in Agaricus blazei
}

\author{
Jiunn-Nan Chu ${ }^{(1)}$, Chiu-Chung Young( ${ }^{(1)}$, Chen-Chung Tan ${ }^{(1)}$, Szu-Pei Wu ${ }^{(2)}$ and Li-Sen Young ${ }^{(3)}$
}

\begin{abstract}
(1)National Chung Hsing University, Department of Soil and Environmental Sciences, Taichung, Taiwan. E-mail: jnc@ms83.url.com.tw, ccyoung@mail.nchu.edu.tw, cctan@dragon.nchu.edu.tw (2)Yuanpei University, Department of Biotechnology, Hsinchu, Taiwan. E-mail: szupeiwu@mail.ypu.edu.tw ${ }^{(3)}$ National Formosa University, Department of Biotechnology, Yunlin, Taiwan. E-mail: Isyoung69@nfu.edu.tw
\end{abstract}

\begin{abstract}
The objective of this work was to assess the productivity and polysaccharide-protein complex content of Agaricus blazei on rice straw medium, in comparison to conventional sawdust, using four casing soils. The A. blazei strain used was BCRC36814 ${ }^{\mathrm{T}}$, purchased from the Food Industry Research and Development Institute, Hsin-Chu, Taiwan. The two media were evaluated as to A. blazei productivity, harvesting time, and production costs. The experimental design used was a randomized complete block, with four replicates. Three local casing soils - Typic Paleudult (CCe), Typic Udorthent (Tq) and Oxyaquic Paleudult (TSp) - were compared to imported peat soil (PS, Saprists, Histosols), used as the control. The productivity of $A$. blazei using Tq and TSp soil was significantly higher. The TSp casing treatment resulted in earlier harvest by at least 14 to 27 days, when compared to the other treatments. The polysaccharide content in $\mathrm{CCe}(13.2 \%)$ and $\mathrm{Tq}$ soils $(13.2 \%)$ did not differ significantly from the PS (13.4\%) and TSp (10.6\%) treatments. Local casing soils decreased the production costs of $A$. blazei cultivation. Composted rice straw can substitute sawdust as the culture medium for $A$. blazei production with increased yield.
\end{abstract}

Index terms: Agaricus blazei, casing soil, loam soil, rice straw, silty clay soil.

\section{Ganho de produtividade e complexo de proteína-polissacarídeos em Agaricus blazei}

\begin{abstract}
Resumo - O objetivo deste trabalho foi avaliar a produtividade e o conteúdo do complexo proteínapolissacarídeos de Agaricus blazei em meio de palha de arroz, em comparação ao de serragem, tendo-se utilizado quatro tipos de solo como camadas de cobertura. Utilizou-se a linhagem BCRC $36814^{\mathrm{T}}$ de $A$. blazei, procedente do Food Industry Research and Development Institute, Hsin-Chu, Taiwan. Os dois meios foram avaliados quanto à produtividade, ao tempo de colheita e aos custos de produção de $A$. blazei. Utilizou-se o delineamento de blocos ao acaso, com quatro repetições. As camadas de cobertura foram compostas por três solos locais - Argissolo Vermelho-Amarelo distrófico (CCe), Neossolo Litólico distrófico (Tq) e Oxyaquic Paleudult (TSp) -, comparados a solo turfoso importado (PS, Saprists, Organossolos Háplicos), utilizado como controle. A produtividade de A. blazei com Tq e TSp foi significativamente maior. O tratamento com TSp resultou em colheita antecipada de 14 a 27 dias, em comparação aos outros tratamentos. O conteúdo de polissacarídeos em CCe $(13,2 \%)$ e Tq $(13,2 \%)$ não diferiu significativamente do em PS $(13,4 \%)$ e TSp $(10,6 \%)$. Os custos de produção foram reduzidos com uso das camadas de cobertura locais. O composto de palha de arroz pode substituir a serragem como meio para o cultivo de $A$. blazei, com aumento de produtividade.
\end{abstract}

Termos para indexação: Agaricus blazei, camadas de cobertura, solo franco-arenoso, palha de arroz, solo argilo-siltoso.

\section{Introduction}

It is widely known that Agaricus blazei Murrill contains active organic ingredients that are associated with the maintenance of human health and the healing of diseases (Lee et al., 2008). Pharmacological studies have shown that bioactive substances, such as polysaccharides and polysaccharide-protein complexes, in A. blazei, function as antioxidants, antimutagenics, antitumorigenics, and anticancer agents (Izawa \& Inoue, 2004; Kimura et al., 2004; Firenzuoli et al., 2008). Therefore, it is not surprising that $A$. blazei has drawn the attention of food scientists and biotechnologists.

Culturing of $A$. blazei requires the spawning growth of the mycelium on a solid culture medium, and subsequent casing of the mycelium with suitable soil to stimulate fruiting-body formation. The composition of the culture medium, i.e., compost, provides nutrients for A. blazei mycelium growth and also affects the

Pesq. agropec. bras., Brasília, v.47, n.1, p.96-102, jan. 2012 
later production of the fruiting body. Agaricus blazei cultivation is commonly done using sawdust as the culture medium (Pokhrel \& Ohga, 2007). In Taiwan, cultivation is usually done using sawdust bag-logs as the major medium. Minor ingredients, such as rice bran, ground corn and calcium carbonate, are used for the spawning stage. However, several researchers have modified the composition of the culture medium by applying agricultural-waste compost to enhance the spawning of $A$. blazei mycelium (Donini et al., 2006) and to increase its overall biological efficiency, which is defined as the ratio of the productivity of an organism to that of its energy supply. Mendonça et al. (2005) used compost from corncobs, wheat straw, rice straw, and several types of grass to produce a medium for $A$. blazei. Pokhrel \& Ohga (2007) mixed cattle-bedding waste and sawdust, as major ingredients, to wheat, rice and barley bran, as supplements, for the culturing of A. blazei. These authors reported a biological efficiency between $28.6-70.9 \%$. In order to cultivate A. blazei, Andrade et al. (2007) used crushed sugarcane and coastcross grass trash as major ingredients, supplemented with ground soybean meal, gypsum and calcitic limestone, as minor ingredients, which resulted in a biological efficiency of $33.6 \%$. Therefore, there is no standard composition for $A$. blazei medium, as it is mixed with various major and minor ingredients, which depend on the available natural resources.

After spawning, A. blazei requires soil casing to allow the production of the fruiting body (sporophores). Growers worldwide commonly use peat soil (PS) for casing of mushrooms (Peyvast et al., 2007). Several researchers have used PS as a fundamental ingredient to mix with various ratios of agricultural or industrial wastes in attempt to replace PS and manage waste issues. Paper waste, tea residue, vine shoot, sugar beet, bark, coir, coal tailings, and spent mushroom substrate have been used by Gülser \& Pekşen, (2003); Noble \& Dobrovin-Pennington, (2005); Peyvast et al., (2007); Pardo-Giménez et al., (2010) whereas Mendonça et al., (2005) and Colauto et al., (2010) have been used as casings for A. bisporus, whereas lime schist, sand and loam soil have been used for A. blazei (Mendonça et al., 2005; Colauto et al., 2010).

Although the submerged fermentation approach has been developed specifically to produce polysaccharides from A. blazei (Lin \& Yang, 2006), the majority of farmers worldwide cultivate the mushroom using traditional methods, i.e., a combination of culturing media and of casing soil.

According to Lee et al. (2008), the market demand for A. blazei is growing rapidly in Brazil, Canada, China, Japan, Korea, and the USA. However, the highest biological efficiency of $A$. blazei cultivation reported so far is only 70.9\% (Pokhrel \& Ohga, 2007), which is difficult to sustain when there is a high demand for the product. Moreover, the use of sawdust and PS, which involves tree farming and mining of the natural resource, poses serious threats to the environment and, at the same time, increases production costs. In addition, the accumulation of heavy metals to toxic levels, which are often associated with $A$. blazei, is speculated to be related to the applied culture media and casing soil (Firenzuoli et al., 2008; Huang et al., 2008).

The objective of this work was to assess the productivity and polysaccharide-protein content of A. blazei on rice straw medium, in comparison to conventional sawdust, using four casing soils.

\section{Materials and Methods}

The A. blazei strain used was BCRC $36814^{\mathrm{T}}$, purchased from The Food Industry Research and Development Institute, Hsin-Chu, Taiwan. The A. blazei stock was maintained on potato dextrose agar (PDA) medium (Difco Laboratories Inc., Detroit, MI, USA) and was activated, subcultured (Pokhrel \& Ohga, 2007), and cultured on sterilized wheat (moisture content of approximately $60 \%$ ) to produce the mother spawn.

Rice straw was collected from the National Chung-Hsing University farm, and matured commercial sawdust medium was purchased from the Q-YO Biotechnology Farm, Ta-Chun, Chang-Hua, Taiwan. Two different culture media were prepared: one with rice straw and the other with sawdust as the major ingredient (70 $\mathrm{g}$ each). Matured rice straw compost was obtained by mincing rice straw into small pieces, which were placed in a plastic container, with moisture adjusted to $60 \%$. Then, rice straw was turned manually every 4-6 days for one month. Minor ingredients for both media were identical: rice bran (20 g), ground soybean $(3 \mathrm{~g})$, yeast powder $(3 \mathrm{~g})$, sucrose $(2 \mathrm{~g})$, and gypsum $(2 \mathrm{~g})$. Rice straw and sawdust media were separately packaged in bag-logs in a $250-\mathrm{mL}$ pot with a total weight of $100 \mathrm{~g}$ each. Both culture media 
for mycelium spawning were sterilized $\left(121^{\circ} \mathrm{C}\right.$ per $1.033 \mathrm{~kg} \mathrm{~cm}^{-2}$ for 1 hour) before use.

Two grams of grain spawn, prepared from the mother spawn, were inoculated on sterilized medium and placed in an incubator at $28^{\circ} \mathrm{C}$ for spawning. The light intensity in the growth chamber was measured at $45 \pm 5 \mathrm{~cm}, 20 \pm 2$ lux, using an TES-1335 Digital Light Meter, (TES Electrical Electronic Corp, Taipei, Taiwan), and the relative humidity was determined at $90 \pm 5 \%$.

The physicochemical properties of each culture media are described in Table 1 . The $\mathrm{C} / \mathrm{N}$ ratio of the matured rice straw compost and of sawdust was 16.8 and 17.8 , respectively.

The two media were evaluated for A. blazei productivity using a peat soil (PS) from Indonesia as the casing soil, at a thickness of 2.0-2.5 $\mathrm{cm}$ (Pokhrel \& Ohga, 2007). The experimental design used was a randomized complete block, with four replicates. Fruiting-body formation on different media was conducted in an incubator at $25^{\circ} \mathrm{C}$ (12 hours, daytime), $22^{\circ} \mathrm{C}$ (12 hours, nighttime), and at $90 \pm 5 \%$ relative humidity.

Table 1. Physicochemical properties of rice straw and sawdust culture media for cultivation of Agaricus blazei.

\begin{tabular}{lcc}
\hline Parameter $^{(1)}$ & \multicolumn{2}{c}{ Culture media } \\
\cline { 2 - 3 } & Rice straw & Sawdust \\
\hline pH & 8.47 & 7.47 \\
EC $\left(\mathrm{mS} \mathrm{cm}^{-1}\right)$ & 4.14 & 2.72 \\
WC $(\%)$ & 52.00 & 56.70 \\
Ash (\%) & 26.50 & 15.00 \\
OM (\%) & 70.50 & 79.20 \\
OC (\%) & 40.80 & 46.00 \\
N (\%) & 2.43 & 2.58 \\
C/N & 16.80 & 17.80
\end{tabular}

${ }^{(1)} \mathrm{EC}$, electric conductivity; WC, water content; OM, organic matter; OC, organic carbon; $\mathrm{N}$, total nitrogen; $\mathrm{C} / \mathrm{N}$, total nitrogen carbon ratio.
In a second experiment, three local casing soils were also evaluated: TSp, coarse-silty, mixed, nonacid, hyperthermic, Oxyaquic Paleudult (FAO-Unesco, 1988); CCe, loamy, mixed, nonacid, hyperthermic, Typic Paleudult (FAO-Unesco, 1988); and $\mathrm{Tq}$, loamy, mixed, nonacid, hyperthermic, Typic Udorthent (FAO-Unesco, 1988). The peat soil (Saprists, Histosols) (FAO-Unesco, 1988) was used as the control. The physicochemical properties of each casing soil are described in Table 2. Non-casing treatment was performed as a negative control, and the casing soils were not sterilized before use. A total of five treatments were conducted with four replicates, in a randomized complete block design. During the cultivation period, $5 \mathrm{~mL}$ of water were added weekly to each treatment. In all casing treatments, matured rice straw was used as the medium to spawn $A$. blazei mycelium.

Harvesting for each casing treatment occurs when the mushroom reaches its highest biomass, i.e., during the immature stage with the veil membrane enclosed and the gills still intact (Mendonça et al., 2005; Pokhrel \& Ohga, 2007). After the initial emergence of the first harvestable mushroom, mushrooms were harvested every two weeks until the eighth week. Total yield (grams per pot) was measured from the cumulative fresh weight of mushrooms (FWM). Biological efficiency (BE, \%) was calculated after eight weeks of harvesting using $\mathrm{BE}=(\mathrm{FWM} / \mathrm{DWC}) \times 100 \%$, in which: DWC, is the dry weight of the culture medium (Andrade et al., 2007).

Polysaccharide-protein complex (PSPC) contents were determined according to Nakajima et al. (2002) and presented as the dry weight of PSPC per dry weight of fruiting body (\%). Lyophilized PSPC was used to determine the polysaccharide content, using the phenol-sulfuric acid method (Chaplin \& Kennedy,

Table 2. Physicochemical properties of casing soils for cultivation of Agaricus blazei.

\begin{tabular}{|c|c|c|c|c|c|c|c|c|c|c|c|}
\hline \multirow[t]{3}{*}{ Casing soil ${ }^{(1)}$} & \multicolumn{11}{|c|}{ Physicochemical properties ${ }^{(2)}$} \\
\hline & $\mathrm{pH}$ & $\mathrm{EC}$ & $\mathrm{BD}$ & PD & $f$ & WHC & Ash & $\mathrm{OM}$ & $\mathrm{OC}$ & $\mathrm{N}$ & $\mathrm{C} / \mathrm{N}$ \\
\hline & & $\left(\mu \mathrm{S} \mathrm{cm} \mathrm{cm}^{-1}\right)$ & \multicolumn{2}{|c|}{------ $\left(\mathrm{g} \mathrm{cm}^{-3}\right)$------ } & \multicolumn{6}{|c|}{------------------------------------------- $(\%)$----------------------------------- } & \\
\hline$\overline{\mathrm{CCe}}$ & 6.01 & 244 & 1.43 & 2.69 & 46.8 & 142 & 95.5 & 3.34 & 1.76 & 0.06 & 29.3 \\
\hline $\mathrm{Tq}$ & 5.82 & 177 & 1.32 & 2.55 & 48.2 & 147 & 94.5 & 4.35 & 2.29 & 0.10 & 22.9 \\
\hline $\mathrm{TSp}$ & 8.02 & 425 & 1.69 & 2.57 & 34.3 & 126 & 98.1 & 1.14 & 0.60 & 0.04 & 15.0 \\
\hline PS & 4.09 & 3,340 & 0.55 & 1.44 & 61.8 & 263 & 10.8 & 85.5 & 45.0 & 2.01 & 22.4 \\
\hline
\end{tabular}

${ }^{(1)} \mathrm{CCe}$, loamy, mixed, nonacid, hyperthermic, Typic Paleudult; Tq, loamy, mixed, nonacid, hyperthermic, Typic Udorthent; TSp, coarse silty, mixed, nonacid, hyperthermic, Oxyaquic Paleudult; PS, Saprists, Histosols. ${ }^{(2)}$ EC, electric conductivity; BD, bulk density; PD, particle density; $f$, porosity; WHC, water holding capacity; OM, organic matter; $\mathrm{OC}$, organic carbon; $\mathrm{N}$, total nitrogen; $\mathrm{C} / \mathrm{N}$, total nitrogen carbon ratio. 
1994). All standards were purchased from Sigma Chemical Co., St. Louis, MO, USA.

The physicochemical properties of each culture media and casing soil were determined. To do that, ash content was analyzed according to Davies (1974); organic matter and organic carbon were determined according to Nelson \& Sommers (1982); and total N was evaluated using the Kjeldahl method (Bremner \& Mulvaney, 1982). The culture media and casing soils were soaked separately in water with a ratio of 1:5 $\left(\mathrm{w} \mathrm{v}^{-1}\right)$, and $\mathrm{pH}$ and electric conductivity (EC) were measured using a $\mathrm{pH}$-electroconductivity meter. Bulk density (BD) was determined using the code technique (Blake \& Hartge, 1986). The particle density (PD) of the soil samples was averaged from two measurements (Blake \& Hartge, 1986). Porosity $(f)$ was calculated as: $[f=(1-\mathrm{BD} / \mathrm{PD}) \times 100 \%]$. Water-holding capacity (WHC) was calculated by dividing the weight of the casing soil saturated with water by the casing soil weight after oven-dried. The texture of the soil indicates the particle-size distribution and the relative proportions of sand $(2.00-0.05 \mathrm{~mm})$, silt $(0.05-0.002 \mathrm{~mm})$, and clay $(<0.002 \mathrm{~mm})$, according to Gee \& Bauder (1986) (Table 3). The minerals $\mathrm{P}, \mathrm{K}, \mathrm{Ca}, \mathrm{Mg}, \mathrm{Fe}$, and $\mathrm{Mn}$ were measured using double acid $\left(\mathrm{HClO}_{4}: \mathrm{HNO}_{3}=1: 4, \mathrm{v}\right.$ $\mathrm{v}^{-1}$ ) analysis (Jones Junior, 2001). Heavy metals (Zn, $\mathrm{Cr}, \mathrm{Cu}, \mathrm{Ni}, \mathrm{Cd}$, and $\mathrm{Pb}$ ) were extracted according to Jones Junior (2001) and analyzed using an inductively coupled plasma spectrophotometer JY 138 Ultrace
ICP-AES, (AST Instruments Corporation, Taipei, Taiwan). The heavy metals and other inorganic elements in the culture media and in the casing soils are described in Table 4.

Statistical analyses were performed using the CoStat Statistical Procedures, and means were compared by Duncan's multiple range test, at $5 \%$ probability. The Pearson product-moment correlation coefficients (r) were computed between total yield and all other evaluated parameters in order to measure the strength of the linear relationship. Then, the $r$ values were assessed for statistical significance using two-tailed Student's t test.

\section{Results and Discussion}

The biological efficiency of $A$. blazei cultivated on both media was compared using PS as the casing soil. The rice straw medium showed a biological efficiency of $76.1 \%$, and the sawdust medium of $40.8 \%$. This indicates that composted rice straw can substitute sawdust as the culture medium, providing a higher biological efficiency. Pokhrel \& Ohga (2007) compared the biological efficiency of $A$. blazei cultured on different ratios of cattle-bedding waste (matured compost) and sawdust medium. These authors observed a biological efficiency of $70.9 \%$ when using $100 \%$ cattle-bedding waste, and of $28.6 \%$ when $25 \%$ cattle-bedding waste was mixed with $75 \%$ sawdust.

Table 3. Texture of casing soils for cultivation of Agaricus blazei.

\begin{tabular}{lcccc}
\hline Casing soil & \multicolumn{3}{c}{ Particle size $\left(\mathrm{g} \mathrm{kg}^{-1}\right)$} & Soil classification \\
\cline { 2 - 4 } & Sand & Silt & Clay & \\
\hline CCe & 124 & 424 & 452 & Loamy, mixed, nonacid, hyperthermic, Typic Paleudult \\
Tq & 362 & 492 & 145 & Loamy, mixed, nonacid, hyperthermic, Typic Udorthent \\
TSp & 887 & 40 & 73 & Coarse silty, mixed, nonacid, hyperthermic, Oxyaquic Paleudult \\
PS & 600 & 289 & 112 & Saprists, Histosols \\
\hline
\end{tabular}

Table 4. Heavy metals and other inorganic elements in the culture media and in the casing soils.

\begin{tabular}{|c|c|c|c|c|c|c|c|c|c|c|c|c|}
\hline \multirow[t]{2}{*}{ Treatment $^{(1)}$} & $\mathrm{Cd}$ & $\mathrm{Pb}$ & $\mathrm{Cr}$ & $\mathrm{Cu}$ & $\mathrm{Ni}$ & $\mathrm{Zn}$ & $\mathrm{P}$ & K & $\mathrm{Ca}$ & $\mathrm{Mg}$ & $\mathrm{Fe}$ & $\mathrm{Mn}$ \\
\hline & \multicolumn{6}{|c|}{ - } & \multicolumn{6}{|c|}{ 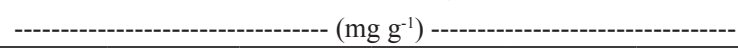 } \\
\hline Rice straw & 0.27 & 3.76 & 9.30 & 9.39 & 5.65 & 93.92 & 21.47 & 58.31 & 25.70 & 4.73 & 0.37 & 0.73 \\
\hline Sawdust & 0.20 & 2.64 & 2.26 & 10.20 & 3.50 & 69.63 & 21.65 & 25.79 & 36.13 & 3.72 & 0.21 & 0.12 \\
\hline $\mathrm{CCe}$ & 10.40 & 10.3 & 70.2 & 35.6 & 56.8 & 187 & 3.83 & 31.40 & 1.57 & 2.31 & 73.8 & 1.18 \\
\hline $\mathrm{Tq}$ & 6.77 & 54.4 & 74.6 & 21.8 & 51.6 & 145 & 3.43 & 20.50 & 3.03 & 6.57 & 51.5 & 0.67 \\
\hline $\mathrm{TSp}$ & 8.44 & 59.2 & 53.5 & 28.8 & 47.8 & 148 & 2.49 & 19.80 & 12.50 & 8.54 & 63.5 & 0.64 \\
\hline PS & 2.11 & 106.0 & 64.0 & 58.4 & 29.5 & 221 & 4.13 & 3.17 & 26.00 & 3.04 & 14.6 & 0.21 \\
\hline
\end{tabular}

${ }^{(1)} \mathrm{CCe}$, loamy, mixed, nonacid, hyperthermic, Typic Paleudult; Tq, loamy, mixed, nonacid, hyperthermic, Typic Udorthent; TSp, coarse silty, mixed, nonacid, hyperthermic, Oxyaquic Paleudult; PS, Saprists, Histosols. 
Agaricus blazei is a secondary saprophyte and, unlike most wood-decomposing primary saprophytes, such as Lentinula edodes, Ganoderma lucidum and Pleurotus ostreatus (Pokhrel \& Ohga, 2007; Gregori et al., 2008), the growth media must be first degraded by microbes or composted in order to allow nutrients to be absorbed by $A$. blazei. These differences may be attributed to the type of culture medium used or to the age of the compost.

Casing of A. blazei mycelium with soil is necessary for fruiting-body formation (Andrade et al., 2007; Pokhrel \& Ohga, 2007). In order to compare the effects of different local casing soils with the imported PS on the production of A. blazei fruiting body, three representative soils were selected in attempt to reduce production costs, using matured rice straw as the medium to spawn A. blazei mycelium. All casing treatments resulted in the fruiting-body formation of A. blazei, except for the non-casing treatment control, in which no mushrooms were produced. Casing with TSp soil resulted in a harvesting time as early as 47 days after casing, while the harvesting time for the Tq, CCe and PS treatments took longer: 61, 74, and 70 days, respectively (Table 5). Therefore, the TSp soil treatment resulted in a 14 to 27 days earlier harvest, in comparison to the other three treatments. The average number of fruiting bodies per pot was highest in $\mathrm{Tq}$ soil (5.5) and lowest in the CCe, TSp and PS casing treatments $(4.5,3.8$ and 3.3, respectively). The average fresh weight (fw) of the fruiting body was highest in the TSp treatment (14.1 g), and lowest in the PS, CCe and Tq soil casings (11.2, 10.5 and $9.3 \mathrm{~g}$, respectively). The total fresh yield per pot was higher in Tq and TSp soil (55.1 and $52.5 \mathrm{~g}$ per pot), and lower in the CCe and PS treatments (44.2 and 35.9 g per pot, respectively).
The biological efficiency was higher in the $\mathrm{Tq}$ and TSp soil treatments (114 and 109\%, respectively), and lower in the CCe and PS casings (91.9 and 74.6\%, respectively). Overall, the productivity of $A$. blazei using $\mathrm{Tq}$ and $\mathrm{TSp}$ as casing soils was significantly higher than with the other two treatments. PS appears to be the poorest one.

TSp and Tq casing soils, with sandy and sandy loam soil texture, respectively, yielded higher productivity, and the PS casing, of sandy loam texture, lower (Table 5). Therefore, the soil texture is not the sole determinant of the productivity of $A$. blazei. Other physicochemical properties of the casing soil may contribute as well. Gülser \& Pekşen (2003) reported that high amounts of organic matter and salt in the casing soil reduced the productivity of $A$. bisporus. Organic matter and EC values in the PS used in the present study were both significantly higher than that of all three local casing soils evaluated (Table 2). This indicates that the high concentration of organic matter and salt in the casing soil may cause reduction in A. blazei yield, similarly as in A. bisporus. The correlation analysis on the heavy metals and other inorganic elements in the casing soils indicates that only $\mathrm{Cu}$ and $\mathrm{Zn}$ showed significant negative correlations with total yield $(\mathrm{p}<0.05$ and $\mathrm{p}<0.01$, respectively). Therefore, high concentrations of $\mathrm{Cu}$ or $\mathrm{Zn}$ in the casing soil most likely reduce total yield. This type of relationship has not been previously reported for A. blazei. The better productivity of A. blazei is probably associated to the lower $\mathrm{Cu}$ and $\mathrm{Zn}$ concentrations in $\mathrm{Tq}$ and $\mathrm{TSp}$ casing soils. In general, the cultivation of $A$. blazei in different casing treatments using rice straw as a medium had a productivity order of $\mathrm{Tq}=\mathrm{TSp}>\mathrm{CCe}>\mathrm{PS}$, which

Table 5. Comparison of different casing soils as to the number of days to the emergence of the first harvestable mushroom, number and fresh weight of fruiting bodies (FB), total fresh yield, and biological efficiency (BE) and to polysaccharide and polysaccharide protein complex (PSPC) contents after eight weeks of harvest of Agaricus blazei with rice straw as the culture medium $^{(1)}$.

\begin{tabular}{|c|c|c|c|c|c|c|c|}
\hline Casing soil(2) & $\begin{array}{c}\text { Emergence } \\
\text { (days) }\end{array}$ & $\begin{array}{l}\text { FB number } \\
\text { (№ per pot) }\end{array}$ & $\begin{array}{c}\text { FB fresh weight } \\
\text { (g per FB) }\end{array}$ & $\begin{array}{l}\text { Total fresh yield } \\
\text { (g per pot) }\end{array}$ & $\mathrm{BE}$ & \multicolumn{2}{|c|}{ 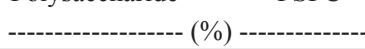 } \\
\hline$\overline{\mathrm{CCe}}$ & $74 a$ & $4.5 b$ & $10.5 b c$ & $44.2 b$ & $91.9 b$ & $13.10 \mathrm{ab}$ & $48.04 \mathrm{a}$ \\
\hline $\mathrm{Tq}$ & $61 b$ & $5.5 \mathrm{a}$ & $9.3 \mathrm{c}$ & $55.1 \mathrm{a}$ & $114.0 \mathrm{a}$ & $13.22 \mathrm{ab}$ & $45.58 \mathrm{ab}$ \\
\hline $\mathrm{TSp}$ & $47 \mathrm{c}$ & $3.8 \mathrm{c}$ & $14.1 \mathrm{a}$ & $52.5 \mathrm{a}$ & $109.0 \mathrm{a}$ & $10.61 b$ & $45.18 \mathrm{ab}$ \\
\hline PS & $70 \mathrm{a}$ & $3.3 \mathrm{c}$ & $11.2 \mathrm{~b}$ & $35.9 \mathrm{c}$ & $74.6 \mathrm{c}$ & $13.41 \mathrm{a}$ & $43.30 \mathrm{~b}$ \\
\hline
\end{tabular}

${ }^{(1)}$ Means followed by equal letters, in the rows, do not differ by Duncan's multiple range test, at $5 \%$ probability. ${ }^{(2)} \mathrm{CCe}$, loamy, mixed, nonacid, hyperthermic, Typic Paleudult; Tq, loamy, mixed, nonacid, hyperthermic, Typic Udorthent; TSp, coarse silty, mixed, nonacid, hyperthermic, Oxyaquic Paleudult; PS, Saprists, Histosols. 
is a good indicative that local soils can substitute imported PS and reduce production costs.

Significantly higher PSPC content was observed in the CCe soil treatment (48\%), when compared to PS (43.4\%); the TSp and Tq soil treatments showed intermediary values and did not differ significantly from the CCe treatment (Table 5). The polysaccharide content in the CCe (13.2\%) and $\mathrm{Tq}(13.2 \%)$ soil treatments did not differ significantly from the PS $(13.4 \%)$ and $\mathrm{TSp}(10.6 \%)$ casing treatments. However, the polysaccharide content was significantly higher in the PS treatment, when compared to TSp soil $(10.6 \%)$. The obtained results are indicators that casing with $\mathrm{Tq}$ soil is more suitable, in comparison to the other three treatments, when polysaccharide/PSPC levels and the total yield of $A$. blazei mushrooms are the focus of production.

Heavy-metal contents were analyzed in dried A. blazei mushrooms for food safety concerns (Table 6). Elements such as $\mathrm{Cd}$ and $\mathrm{Pb}$ affect human health and, therefore, are strictly regulated. Based on the European Union (2006) regulation on the maximum levels for certain contaminants in foodstuffs, the regulated concentrations of $\mathrm{Cd}$ should not exceed $0.2 \mu \mathrm{g} \mathrm{g} \mathrm{g}^{-1}$ fw in A. bisporus, P. ostreatus and L. edodes, and $1.0 \mu \mathrm{g} \mathrm{g}^{-1} \mathrm{fw}$ in other mushrooms, such as A. blazei. With regard to $\mathrm{Pb}$, there is no regulation on A. blazei, but the limit for A. bisporus, P. ostreatus and L. edodes is $0.3 \mu \mathrm{g} \mathrm{g}^{-1} \mathrm{fw}$ (European Union, 2008). Therefore, the European Union regulation was considered as a guideline for A. blazei mushrooms in the present study. The Cd content was highest in the mushrooms from CCe soil treatment $\left[1.08 \mu \mathrm{g} \mathrm{g}^{-1}\right.$ of dry weight $\left.(\mathrm{dw})\right]$ and lowest in the TSp treatment $\left(0.92 \mu \mathrm{g} \mathrm{g}^{-1} \mathrm{dw}\right) . \mathrm{Pb}$ was highest in the CCe casing treatment $\left(1.61 \mu \mathrm{g} \mathrm{g}^{-1} \mathrm{dw}\right)$,

Table 6. Heavy metal contents in dried fruiting bodies of Agaricus blazei under different casing treatments ${ }^{(1)}$.

\begin{tabular}{|c|c|c|c|c|c|c|}
\hline \multirow[t]{2}{*}{ Casing soil $^{(2)}$} & $\mathrm{Cd}$ & $\mathrm{Pb}$ & $\mathrm{Cr}$ & $\mathrm{Cu}$ & $\mathrm{Ni}$ & $\mathrm{Zn}$ \\
\hline & \multicolumn{6}{|c|}{ 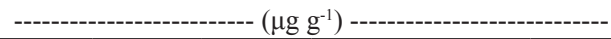 } \\
\hline $\mathrm{CCe}$ & $1.08 \mathrm{a}$ & $1.61 \mathrm{a}$ & $2.69 \mathrm{a}$ & $23.3 b$ & $0.71 \mathrm{a}$ & $170 \mathrm{a}$ \\
\hline $\mathrm{Tq}$ & $0.98 \mathrm{bc}$ & $1.44 \mathrm{ab}$ & $0.44 \mathrm{c}$ & $23.0 \mathrm{~b}$ & $0.55 b$ & $155 b$ \\
\hline TSp & $0.92 \mathrm{c}$ & $1.18 \mathrm{~b}$ & $0.72 b$ & $20.5 c$ & $0.43 \mathrm{c}$ & $152 b$ \\
\hline PS & $1.04 \mathrm{ab}$ & $0.35 \mathrm{c}$ & $0.75 b$ & $26.5 \mathrm{a}$ & $0.68 \mathrm{a}$ & $151 b$ \\
\hline
\end{tabular}

(1)Means followed by equal letters, in the rows, do not differ by Duncan's multiple range test, at $5 \%$ probability. All concentrations were pooled from four successive harvests. ${ }^{(2)} \mathrm{CCe}$, loamy, mixed, nonacid, hyperthermic, Typic Paleudult; Tq, loamy, mixed, nonacid, hyperthermic, Typic Udorthent; TSp, coarse silty, mixed, nonacid, hyperthermic, Oxyaquic Paleudult; PS, Saprists, Histosols. and lowest in the PS treatment $\left(0.35 \mu \mathrm{g} \mathrm{g}^{-1} \mathrm{dw}\right)$. The levels of $\mathrm{Cd}$ and $\mathrm{Pb}$ from the pooled mushroom were 0.10 and $0.16 \mu \mathrm{g} \mathrm{g}^{-1} \mathrm{fw}$, respectively (average water content of harvested mushroom is $90 \%$ ), both below the European Union regulation. These results are lower than those reported by $\mathrm{Xu}$ (1999), in which the Cd content of $A$. blazei fresh fruiting body ranged from 0.3 to $0.35 \mu \mathrm{g} \mathrm{g}^{-1}$. These differences may be due to the contributions of heavy metals from different media or of casing materials that resulted in the levels accumulated within the fruiting body (Kalac \& Svoboda, 2000). Therefore, the selection of culturing materials for food safety purposes is an important consideration for A. blazei cultivation. Overall, the relatively low content of $\mathrm{Cd}$ and $\mathrm{Pb}$ in $A$. blazei is in accordance with the European Union regulation for safe mushrooms.

\section{Conclusions}

1. Recycling of rice straw agricultural waste can substitute sawdust medium for Agaricus blazei production with increased yield.

2. Casing soils from local soil resources can substitute imported peat soil and decrease the production costs of A. blazei cultivation.

3. $\mathrm{Cu}$ and $\mathrm{Zn}$ content in the casing soils show significant negative correlations with $A$. blazei total yield.

4. The polysaccharide-protein complex content in A. blazei fruiting bodies is significantly increased using local Typic Paleudult soil, in comparison to peat soil.

\section{Acknowledgements}

To National Science Council and Council of Agriculture, for support; and to Dr. Robert Glew and Dr. Li-Hao Young, for their critical comments on the manuscript.

\section{References}

ANDRADE, M.C.N. de; KOPYTOWSKI FILHO, J.; ALMEIDA MINHONI, M.T. de; COUTINHO, L.N.; FIGUEIREDO, M.B. Productivity, biological efficiency, and number of Agaricus blazei mushrooms growth in compost in the presence of Trichoderma sp. and Chaetomium olivacearum. Brazilian Journal of Microbiology, v.38, p.243-247, 2007.

BLAKE, G.R.; HARTGE, K.H. Particle density. In: KLUTE, A. (Ed.). Methods of soil analysis. Part 1 - physical and mineralogical 
methods. $2^{\text {nd }}$ ed. Madison: Soil Science Society of America, 1986. p.377-382. (SSA book series, 5).

BREMNER, J.M.; MULVANEY, C.S. Nitrogen-total. In: PAGE, A.L.; MILLER, R.H.; KENNEY, D.R. (Ed.). Methods of soil analysis. Part 2 - microbiological and biochemical properties. New York: Soil Science Society of America, 1982. p.595-624. (SSA book series, 5).

CHAPLIN, M.F.; KENNEDY, J.F. (Ed.). Carbohydrate analysis: a practical approach. $2^{\text {nd }}$ ed. Oxford: Oxford University, 1994. 228p.

COLAUTO, N.B.; SILVEIRA, A.R. da; EIRA, A.F. da; LINDE, G.A. Alternative to peat for Agaricus brasiliensis yield. Bioresource Technology, v.101, p.712-716, 2010.

DAVIES, B.E. Loss-on-ignition as an estimate of soil organic matter. Soil Science Society of America Journal, v.38, p.150-151, 1974.

DONINI, L.P.; BERNARDI, E.; NASCIMENTO, J.S. do. Desenvolvimento in vitro de Agaricus brasiliensis em meios suplementados com diferentes farelos. Pesquisa Agropecuária Brasileira, v.41, p.995-999, 2006.

EUROPEAN UNION. Commission Regulations (EC) No 1881/2006 of 19 December 2006. Setting maximum levels for certain contaminants in foodstuffs. Official Journal of the European Union, L 364/5-364/24, 2006.

EUROPEAN UNION. Commission Regulations (EC) No 629 of 2 July 2008. Amending Regulation (EC) No 1881/2006 setting maximum levels for certain contaminants in foodstuffs. Official Journal of the European Union, L 173/6-173/9, 2008.

FAO-UNESCO: soil map of the world. Rome: Food and Agriculture Organization of the United Nations, 1988. 96p. (FAO. World soil resources report, 60).

FIRENZUOLI, F.; GORI, L.; LOMBARDO, G. The medicinal mushroom Agaricus blazei Murrill: review of literature and pharmaco-toxicological problems. Evidence-Based Complementary and Alternative Medicine, v.5, p.3-15, 2008.

GEE, G.W.; BAUDER, J.W. Particle-size analysis. In: KLUTE, A. (Ed.). Method of soil analysis. Part 1 - physical and mineralogical methods. $2^{\text {nd }}$ ed. Madison: Soil Science Society of America, 1986. p.383-411. (SSA book series, 5).

GREGORI, A.; PAHOR, B.; GLASER, R.; POHLEVEN, F. Influence of carbon dioxide, inoculum rate, amount and mixing of casing soil on Agaricus blazei fruiting bodies yield. Acta Agriculturae Slovenica, v.91, p.371-378, 2008.

GÜLSER, C.K.; PEKŞEN, A. Using tea waste as a new casing material in mushroom (Agaricus bisporus (L.) Sing.) cultivation. Bioresource Technology, v.88, p.153-156, 2003.

HUANG, J.C.; LI, K.B.; YU, Y.R.; WU, H.; LIU, D.L. Cadmium accumulation in Agaricus blazei Murrill. Journal of the Science of Food and Agriculture, v.88, p.1369-1375, 2008.
IZAWA, S.; INOUE, Y. A screening system for antioxidants using thioredoxin-deficient yeast: discovery of thermostable antioxidant activity from Agaricus blazei Murill. Applied Microbiology and Biotechnology, v.64, p.537-542, 2004.

JONES JUNIOR, J.B. Laboratory guide for conducting soil tests and plant analysis. Boca Raton: CRC, 2001.363p.

KALAC, P.; SVOBODA, L. A review of trace element concentrations in edible mushrooms. Food Chemistry, v.69, p.273-281, 2000.

KIMURA, Y.; KIDO, T.; TAKAKU, T.; SUMIYOSHI, M.; BABA, K. Isolation of an anti-angiogenic substance from Agaricus blazei Murill: its antitumor and antimetastatic actions. Cancer Science, v.95, p.758-64, 2004.

LEE, I.P.; KANG, B.H.; ROH, J.K.; KIM, J.R. Lack of carcinogenicity of lyophilized Agaricus blazei Murill in a F344 rat two year bioassay. Food and Chemical Toxicology, v.46, p.87-95, 2008.

LIN, J.H.; YANG, S.S. Mycelium and polysaccharide production of Agaricus blazei Murrill by submerged fermentation. Journal of Microbiology, Immunology and Infection, v.39, p.98-108, 2006.

MENDONÇA, M.M.; KASUYA, M.C.M.; CADORIN, A.; VIEIRA, A.J. Agaricus blazei cultivation for a living in Brazil. In: SHIITAKE cultivation. Seoul: MushWorld, 2005. p.246-257.

NAKAJIMA, A.; ISHIDA, T.; KOGA, M.; TAKEUCHI, T.; MAZDA, O.; TAKEUCHI, M. Effect of hot water extract from Agaricus blazei Murill on antibody-producing cells in mice. International Immunopharmacology, v.2, p.1205-1211, 2002.

NELSON, D.W.; SOMMERS, L.E. Total carbon, organic carbon, and organic matter. In: PAGE, A.L.; MILLER, R.H.; KENNEY, D.R. (Ed.). Methods of soil analysis. Part 2 - microbiological and biochemical properties. New York: Soil Science Society of America, 1982. p.539-579. (SSA book series, 5).

NOBLE, R.; DOBROVIN-PENNINGTON, A. Partial substitution of peat in mushroom casing with fine particle coal tailings. Scientia Horticulturae, v.104, p.351-367, 2005.

PARDO-GIMÉNEZ， A.; ZIED， D.C.; PARDO-GONZÁLEZ, J.E. Utilización de compost agotado de champiñón como capa de coberturas en nuevos ciclos de producción. Pesquisa Agropecuária Brasileira, v.45, p.1164-1171, 2010.

PEYVAST, G.H.; SHAHBODAGHI, J.; REMEZANI, P.; OLFATI, J.A. Performance of tea waste as a peat alternative in casing materials for bottom mushroom (Agaricus bisporus (L.) Sing.) cultivation. Biosciences, Biotechnology Research Asia, v.4, p.484-494, 2007.

POKHREL, C.P.; OHGA, S. Cattle bedding waste used as a substrate in the cultivation of Agaricus blazei Murill. Journal of the Faculty of Agriculture Kyushu University, v.52, p.295-298, 2007.

XU, C.S. Effects of pernicious trace elements on human health. Guangdong Trace Elements Science, v.6, p.1-3, 1999.

Received on March 11, 2011 and accepted on December 12, 2011

Pesq. agropec. bras., Brasília, v.47, n.1, p.96-102, jan. 2012 